
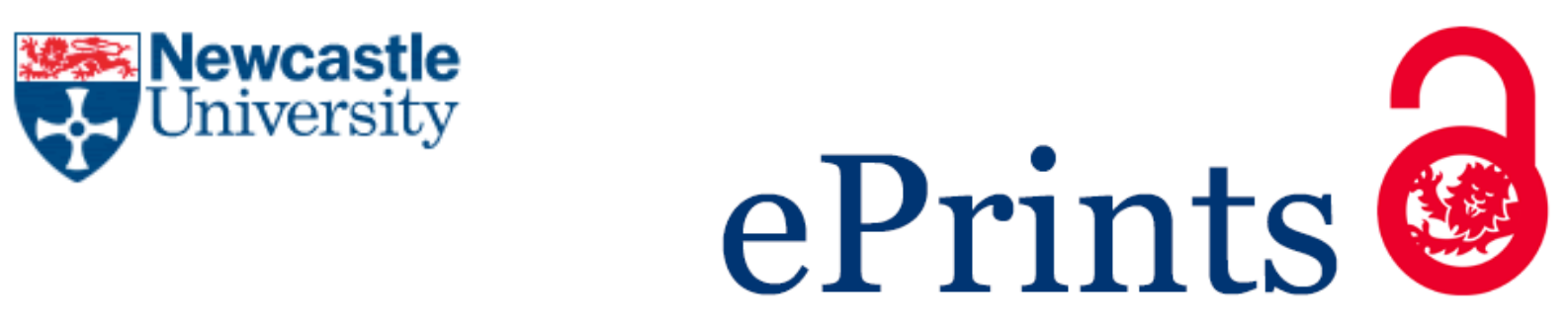

\begin{abstract}
Alamanos E, Bourlakis M, Tzimitra-Kalogianni I. Segmenting Greek tomato consumers: Policy and marketing insights towards a healthy diet. British Food Journal 2013, 115(4), 488-507.
\end{abstract}

\title{
Copyright:
}

This article is (C) Emerald Group Publishing and permission has been granted for this version to appear here (http://eprint.ncl.ac.uk/). Emerald does not grant permission for this article to be further copied/distributed or hosted elsewhere without the express permission from Emerald Group Publishing Limited.

DOI link to article:

http://dx.doi.org/10.1108/00070701311317801

Date deposited:

$08 / 04 / 2015$ 


\title{
Segmenting Greek tomato consumers: \\ Policy and marketing insights towards a healthy diet
}

\section{Eleftherios Alamanos*}

email: ealamanos@lincoln.ac.uk

Tel: 00441522835691

Eleftherios Alamanos is a Lecturer in Marketing at the University of Lincoln Business School, United Kingdom.

\author{
Michael Bourlakis \\ email: Michael.Bourlakis@brunel.ac.uk
}

Michael Bourlakis is a Professor in Supply Chain Management at Brunel University Business School, United Kingdom.

\section{Irini Tzimitra-Kalogianni}

email: tzim@agro.auth.gr

Irini Tzimitra-Kalogianni is a Professor in Food Marketing at the Aristotle University of Thessaloniki Department of Agricultural Economics, Greece.

* Corresponding Author

\begin{abstract}
Purpose: The study examines consumer behaviour towards fresh tomatoes and reveals the factors that influence consumption leading to an adoption of a healthy diet. The major consumer segments are also illustrated and interventions to promote tomato consumption are suggested.

Design/Methodology: A consumer survey was carried out in Thessaloniki (Greece) and 337 self-reported questionnaires from tomato consumers were used in the analysis.

Findings: The findings from Principal Component Analysis indicate that the main factors that influence consumption of fresh tomatoes are: "Nutrition Value",
\end{abstract}


"Organoleptic Characteristics" of tomatoes and "Eating Habits" of consumers. A Two Step Cluster Analysis revealed three segments of tomato consumers labelled as "Tomato-Loyals", "Sensorialists" and "Health-Conscious".

Practical Implications: The findings reveal the consumption characteristics of each consumer segment where tailored social marketing plans can be developed based on this work. The findings will be of interest to food marketers and food policy makers, as they can contribute to addressing obesity problems in Europe in general and Mediterranean countries in particular.

Originality/Value: The paper identifies the underlying reasons for eating fresh tomatoes which can lead to the adoption of a healthy diet and can support policies towards that. It also reveals new consumer segments and highlights differences between them. In addition, it highlights the interventions to increase tomato consumption of each segment. Finally, it employs a cluster analysis technique, TwoStep Cluster Analysis, which has not been widely used in marketing research..

Keywords: Consumer Segmentation, Consumer Policy, Tomatoes, Diet, Greece

\section{Introduction}

Dietary-related diseases are one of the most important health issues. These diseases are still widespread despite recommendations and interventions from various scientific and regulatory bodies. Some of the recommendations aim at changing consumers' attitudes and behaviour by promoting healthy eating and suggest to consumers to eat more fruit, vegetables, and fish, and less fatty and sugary food (Chrysochou et al., 2010). Health care expenses represent, on average, 14\% of the total expenses in the countries-members of the European Union (World Health Organisation, 2009) and therefore these recommendations are aiming at reducing public expenses for health in these countries. However, a large proportion of the population in several countries does not follow these recommendations, especially regarding fruit, vegetables, and fish intake, mainly due to inappropriate communication strategies which fail to address the target audience (Pieniak et al., 2010a). In Greece, $22.5 \%$ of the adult population is considered as obese, displaying a Body Mass Index greater than thirty which ranks Greece second in terms of obesity in Europe following the UK (World Health Organisation, 2011). In contrast, other 
Mediterranean countries are ranked towards the lower end of this scale, specifically, Spain $\left(10^{\text {th }}\right)$, Portugal $\left(15^{\text {th }}\right)$, and Italy $\left(25^{\text {th }}\right)$. Cyprus, a country with similar dietary habits to Greece is ranked nineteenth. Fruit and vegetable consumption is an indicator of healthy eating habits (Bertail and Caillavet, 2008). According to the European Nutrition and Health Report conducted on behalf of the European Commission (2009), only four European countries, namely, Poland, Germany, Italy and Austria, achieved the recommended 5-A-Day servings of fruit and vegetables, with dietary habits in Greece deviating from those of a typical Mediterranean diet.

It is worth noting that consumer choice towards food is not always rational (Verbeke et al., 2007); consumers are aware of the link between food and health (Honkanen, 2010), even so they usually tend to adopt unhealthy diets. Given that decision making regarding food is a complex procedure, a substantial number of studies has examined consumer attitudes (Kemp et al., 2010, Hjelmar, 2011, Hoefkens et al., 2011, Verbeke et al., 2007, Korzen et al., 2011, Miljkovic and Effertz, 2010, Browyer et al., 2009, Binnekamp and Ingenbleek, 2008, Espejel et al., 2008, Thogersen et al., 2010, Michaelidou and Hassan, 2010, Guerrero et al., 2009, Barreiro-Hurle et al., 2010, Meneely et al., 2009, Perez-Cueto et al., 2010, Grunert et al., 2009, Michon et al., 2010). These studies attempt to explain how consumption is influenced by the demographic and socio-economic characteristics of consumers, product quality cues (e.g. country of origin, price), and lifestyle.

This paper examines tomato consumption in Greece, given the high rate of obesity in this country. The latter has a big impact on the public expenses for health (World Health Organisation, 2009), and on the business sector, as obese employees tend to be absent from work more days than their non-obese counterparts due to illness (PerezCueto et al., 2010, Trogdon et al., 2008). Tomato is the primary vegetable consumed in the world after potato (Causse et al., 2010) and its consumption can contribute to maintaining good health due to antioxidant properties of lycopene, a carotenoid compound contained in tomatoes which it is believed that lowers the risk of cancer (Preedy and Watson, 2008, Frusciante et al., 2007, Chang et al., 2006). Subsequently, the paper will look into the link between tomato consumption and diet.

The paper is organised as follows. The next section presents a comprehensive literature review of consumer attitudes towards horticultural products and tomato followed by a discussion on the methodology employed in the study. The main 
findings are provided in another section whilst discussion and conclusions are provided towards the end of this paper.

\section{Consumers' attitudes and segmentation towards horticultural products and tomatoes}

Previous studies on tomato consumption (Brueckner et al., 2007, Le and Ledauphin, 2006, Jahns et al., 2001, Pagliarini et al., 2001) tend to focus on consumer taste preferences and not necessarily on consumer attitudes. Taking into account that scarcity of relevant work, this section will initially analyse consumer behaviour towards vegetables and, subsequently, similar analysis will follow for tomato products. We are confident that the key findings from previous studies on vegetable consumption will also apply to tomato consumption and we anticipate this approach to support and facilitate the theoretical underpinnings of our empirical work.

Hence, in their examination of vegetable consumption, Verbeke and Pieniak (2006) identified health prevention, hedonism, and nutrition as the main reasons that consumers consider as important for eating fresh vegetables. However, several other factors influence this consumption too. For instance, food related lifestyle, a concept first introduced in the mid-nineties aiming at studying the role of life values towards food and eating (Grunert et al., 2011), was found to influence the consumption of packed vegetables as the main reasons for selecting these products are convenience and saving time (Ragaert et al., 2004, Michon et al., 2010).

The available time for purchases together with factors such as involvement with food (Berning et al., 2010), nutrition knowledge, individual's characteristics, economic conditions, and health concerns influence the use of labels by consumers. Although the use of label improves consumer diets (Barreiro-Hurle et al., 2010), there is a gap in the literature regarding the information that consumers would like to have available on food labels in general and vegetable labels in particular. Previous research has focused mainly on the information that already exists on food labels and does not examine the consumer perspective on this (Berning et al., 2010). Despite that, vegetables, tomatoes included, are a low-involvement product (Gething et al., 2011) and their consumption can contribute in maintaining good health (Geeroms et al., 2008). Therefore, the empirical work of this study contributed to this gap in the literature by examining the information that consumers would like to have available when they are purchasing tomatoes. 
Another factor in relation to vegetable intake is the seasonal consumption (Verbeke and Pieniak, 2006) and whether the availability of particular types of vegetables, especially in rural areas, could influence purchases. As this factor has not been addressed to a great extent in the relevant literature (Locke et al., 2009), our empirical work examined seasonal tomato consumption too.

Vegetable intake is also influenced by income, as low income consumers display low vegetable consumption (Bertail and Caillavet, 2008) for both organic (Boccaletti and Nadella, 2000) and the higher quality classes of vegetables (e.g Class I vegetables in UK) (Leather, 1995). This is due to the higher price of these particular classes of vegetables compared to their lower class counterparts (e.g. Class II vegetables in UK). Elaborating on the above, Perez-Cueto et al. (2010) suggest that non-obese consumers tend to be more interested than their obese counterparts in dimensions of quality, such as freshness and organic production indicating a greater interest in the link between health and food consumption. Therefore, a key element when examining the influence of price on consumer behaviour is the degree to which several quality cues are tradedoff against price (Grunert et al., 2009). Hence, organic and higher quality class vegetables should provide high satisfaction to consumers (Ness et al., 2010).

Organic vegetable intake is also influenced by consumers' subjective and objective knowledge. Subjective knowledge is a better predictor as it increases the perceived certainty about selecting organic vegetables (Pieniak et al., 2010b). Supporting the latter, Thogersen (2009) notes that uncertainty about the concept of organic vegetables is the main barrier for their consumption; as consumers tend to display a low level of trust in organic food quality certifications (Botonaki et al., 2006).

The interpretation of consumer behaviour towards food in general and vegetables in particular can be facilitated by consumer segmentation (Pieniak et al., 2010a) and it can support the design of social marketing and policy campaigns targeting specific consumer segments (Geeroms et al., 2008). In relation to vegetable consumer segmentation, past studies have mainly focused on consumer preferences for quality cues (Le and Ledauphin, 2006) and the level of consumption (Bertail and Callivet, 2008, Brueckner et al. 2007). Specifically, Bertail and Caillavet (2008) segmented consumers in France on the basis of the level of consumption. They revealed six segments which displayed statistically significant differences in terms of income, education, household size, and to the importance they attach to price as a selection criterion. In relation to tomato, Le and Ledauphin (2006) segmented tomato 
consumers in France based on their preferences for tomato attributes. They identified three segments: the first two segments are similar as consumers like sweet, small and flavourful tomatoes, whereas consumers of the third segment do not like sweet tomatoes. Brueckner et al. (2007) examined the low vegetable intake of children and young consumers, and conducted a series of taste experiments using cherry tomatoes, the taste of which had been modified in terms of sweetness and sourness by using different concentrations of sugar and acids. They revealed three clusters with different preferences for acid and sugar concentrations, but found no significant differences regarding gender, age and body weight.

The literature review presented in this section identifies the main factors which influence tomato consumption and therefore can lead to an adoption of healthier dietary habits. However, further research on the underlying consumer food-related attitudes which are associated with obesity is required in order to tackle its current and future consequences in the society, as not all the determinants of obesity have been investigated in depth (Perez-Cueto et al., 2010, Nayga, 2008). This study examines preferences and behaviour of consumers in Thessaloniki towards fresh tomato consumption. The main objective is to illustrate the factors that influence tomato consumption and to segment consumers aiming at increasing vegetable consumption in general and tomato consumption in particular in each segment. Therefore, the study employed benefit beliefs envisaging that the possible adoption of healthier diets can contribute to tackling obesity problems in Greece. We believe that a segmentation of consumers can be a significant contributor in designing tailored social marketing and social policy campaigns to promote healthy eating for respective consumer segments (Geeroms et al., 2008). Hence, our study adds to current knowledge by examining the available information on label that each consumer segment seeks and the differences between them. The examination of these differences can increase the success of tailored social marketing campaigns aiming at tackling obesity. Also, the availability of this information at the time of purchase can increase tomato consumption, and contribute in reducing the public health expenses in European countries. Therefore, this study addresses the following research questions:

RQ1: What are the most important reasons for consumers towards tomato consumption?

RQ2: What kind of information do consumers want available on the shelf label or on the packaging when they buy tomatoes? 
RQ3: Can different segments of consumers be identified based on various reasons that consumers consider important for eating tomatoes?

RQ4: Are there any differences between consumer segments in terms of purchasing behaviour and attitudes towards consumption of tomatoes?

\section{Methodology}

\section{Subjects and Sampling}

The survey was conducted in Thessaloniki (Greece). Thessaloniki is a metropolitan area, the largest city in northern Greece and several consumer behaviour studies have been conducted in that area in the past (Botonaki and Mattas, 2010, Tzavaras et al., 2010, Tsakiridou et al., 2008, Fotopoulos and Krystallis, 2003, Tzimitra-Kalogianni et al., 1999). The whole research process was initiated after 2005 and the data were collected by distributing a self-completion questionnaire to potential tomato consumers responsible for food purchasing in their households (Pieniak et al., 2010a).

\section{Procedure}

Sampling was conducted in two stages, employing the proportional stratified sampling technique in the greater area of Thessaloniki and random sampling technique within each area respectively. The number of questionnaires collected in each area was proportional to the respective population (Malhotra and Birks, 2007). The questionnaires were distributed via the drop-off technique. A random route was followed in each area of greater Thessaloniki. A number of streets was randomly selected in each area and a questionnaire was given to every tenth household in each street. Appointments were arranged to collect the questionnaires and 337 questionnaires were collected at the end.

\section{Methods}

A dichotomous question was included in the beginning of the questionnaire (see Appendix) asking participants whether they eat tomatoes and aiming to exclude the non-consumers. It was followed by a set of statements examining the reasons for eating tomatoes, aiming at illustrating the most important factors which influence tomato consumption. The second, third, and fourth sections of the questionnaire were aiming to examine participants' buying behaviour. The fifth section examined participants' organic tomato consumption. A set of statements exploring participant attitudes towards fresh tomatoes comprised the penultimate section of the 
questionnaire. Here, we aim to facilitate the design of appropriate health marketing campaigns and policies and to examine strategies for addressing the target segments. The last section of the questionnaire examined the socio-economic and demographic characteristics of the participants. A pilot study with 65 participants proportionally distributed to the strata was conducted to test the questionnaire.

Principal Component Analysis with Varimax rotation was employed to reveal the benefit consumers sought from fresh tomato consumption. The number of the extracted factors was based on the Eigenvalue criterion, according to which factors with Eigenvalues greater or equal to one are retained in the final model (Malhotra and Birks, 2007). Factor scores were employed in Two-Step Cluster Analysis to segment consumers. Factor scores were used instead of raw variables to prevent problems of multicollinearity (Grunert et al., 2009). This technique was considered as more reliable than K-Means and Hierarchical Cluster Analysis as it produces better results with large sample sizes whilst K-Means Cluster Analysis assumes that the number of clusters is known in advance (Norusis, 2007). The number of clusters was determined by employing the Bayesian Information Criterion (BIC) (Honkanen, 2010). Nonparametric Kruskal-Wallis tests were employed to examine the differences among segments by comparing the means of the metric variables. Post-hoc Mann-Whitney tests followed Kruskal-Wallis tests to facilitate the better interpretation of any differences. Benferonni corrections were applied at the post-hoc tests to reduce Type I error. To ensure that the cumulative Type I error is below 0.05, the criterion for significance of differences was set at 0.0167. Finally, differences among nominal variables were examined by applying chi-square $\left(\chi^{2}\right)$ tests (Field, 2005).

\section{Findings}

\section{Factors influencing the consumption of fresh tomatoes}

Most consumers who participated in the study $(311,92.3 \%)$ eat fresh tomatoes and their replies were used in the subsequent analysis. A Principal Component Analysis was employed to examine the reasons for eating fresh tomatoes (Table I). Three consumption factors (Table I) were revealed explaining 31.06\%, 22.15\% and $13.26 \%$ of variance respectively (total 66.47\%). Internal reliabilities of the first two factors were considered as satisfactory for an exploratory study (Peterson, 1994), while for the third factor, Cronbach's alpha coefficient could not be estimated as the factor constituted of only one item. However, this factor was retained in the model as it 
increased the total variance explained and it was included in the subsequent analysis. Based on the variable loadings, the three factors were labelled as "Nutrition Value", “Organoleptic Characteristics" and "Eating Habits" (Table I).

Table I: Principal Components Analysis of the reasons of fresh tomatoes consumption

\begin{tabular}{|l|r|r|r|r|}
\hline \multirow{2}{*}{ Benefit sought from fresh tomato consumption } & \multicolumn{2}{|c|}{ Factors } & \multirow{2}{*}{ Communalities } \\
\cline { 2 - 5 } & $\begin{array}{c}\text { Nutritional } \\
\text { Value }\end{array}$ & $\begin{array}{c}\text { Organoleptic } \\
\text { Characteristics }\end{array}$ & $\begin{array}{c}\text { Eating } \\
\text { Habits }\end{array}$ & \\
\hline It is healthy food & 0.856 & & & 0.772 \\
\hline It is nutritious food & 0.836 & & & 0.743 \\
\hline They are rich in vitamins, fibres and antioxidants & 0.758 & & & 0.593 \\
\hline It is light food & 0.658 & & & 0.547 \\
\hline I like the flavour & & & 0.779 & 0.611 \\
\hline They have nice aroma & & 0.757 & & 0.624 \\
\hline It is a refreshing salad over summer & & 0.638 & & 0.510 \\
\hline I do not eat other vegetables as salad & & & 0.957 & 0.916 \\
\hline Cronbach' s alpha & & & & \\
\hline
\end{tabular}

$\left(\right.$ KMO index $=0.751$, Barlett's test of sphericity: $\left.\mathrm{x}^{2}(28)=617,372, \mathrm{p}<0,001\right)$

\section{Consumer segmentation}

Factor scores were employed in a Two Step Cluster Analysis that revealed three segments of consumers (Table II). Based on the factors characterising each segment, the first one was labelled "Tomato-Loyals", characterised by the factor "Eating Habbits" which is represented by the statement "I do not eat other vegetables as salad". The second one was labelled "Sensorialists",described by the factor "Organoleptic Characteristics", as its members tend to select vegetables based on their organoleptic characteristics. Finally, the third segment was labelled "HealthConscious", characterised by the factor "Nutritional Value", as its members tend to select which vegetables they will eat based on nutritional value.

Table II: Segments Centroids

\begin{tabular}{|c|c|c|c|c|c|c|}
\hline \multirow{2}{*}{ Segments } & \multicolumn{2}{|c|}{$\begin{array}{c}\text { Reg. Factor Scores } \\
\text { Eating Habits }\end{array}$} & \multicolumn{2}{c|}{$\begin{array}{c}\text { Reg. Factor Scores } \\
\text { Organoleptic Characteristics }\end{array}$} & \multicolumn{2}{c|}{$\begin{array}{c}\text { Reg. Factor Scores } \\
\text { Nutritional Value }\end{array}$} \\
\cline { 2 - 7 } & Mean & Standard Deviation & Mean & Standard Deviation & Mean & Standard Deviation \\
\hline 1 & $\mathbf{1 . 2 9 4 4 1 1 3}$ & 0.97903416 & -0.4716240 & 0.63052196 & -0.5270645 & 0.79906035 \\
\hline 2 & -0.6721997 & 0.43500885 & $\mathbf{- 0 . 2 6 7 2 8 1 6}$ & 1.22529704 & -0.6859380 & 0.89291686 \\
\hline 3 & -0.1019998 & 0.70145818 & 0.4277628 & 0.75579606 & $\mathbf{0 . 7 7 3 3 5 0 2}$ & 0.49226296 \\
\hline Combined & 0.0000000 & 1.00000000 & 0.0000000 & 1.00000000 & 0.0000000 & 1.00000000 \\
\hline
\end{tabular}

Socioeconomic and Demographic characteristics of segments

With regard to age, statistically significant differences were found between "Tomato-Loyals" and "Health-Conscious. The former segment has a youngest profile 
base, with $62.1 \%$ of consumers being between 18 and 35 years old, while the latter has an oldest profile base with $64 \%$ being older than 36 years (Table III).

Differences in marital status were found statistically significant, as "TomatoLoyals" differ from the remaining segments. Most "Tomato-Loyals" are single, while most consumers of the two other segments are married (Table III). Regarding household income (before tax), significant differences were found between "HealthConscious" and the other segments as "Health-Conscious" have a higher household income and differ significantly compared to the other segments especially when there is a presence of a working mother in the household (Table III). However, no significant differences were found regarding gender, education, and the presence of children in the family.

Table III: Synthesis, Socio-economic and Demographic characteristics of Segments

\begin{tabular}{|c|c|c|c|c|c|}
\hline \multicolumn{2}{|c|}{ Segments' Synthesis } & $\begin{array}{l}\text { Tomato- } \\
\text { Loyals }\end{array}$ & Sensorialists & $\begin{array}{c}\text { Health- } \\
\text { Conscious }\end{array}$ & \multirow{4}{*}{$\begin{array}{l}\text { Statistical Significance } \\
\text { of the Differences } \\
\text { Among Segments }\end{array}$} \\
\hline \multicolumn{2}{|c|}{ Number of Consumers } & 66 & 106 & 139 & \\
\hline \multicolumn{2}{|c|}{ Total \% } & $21.2 \%$ & $34.1 \%$ & $44.7 \%$ & \\
\hline \multicolumn{2}{|c|}{$\begin{array}{l}\text { Socioeconomic and Demographic } \\
\text { Characteristics }\end{array}$} & $\begin{array}{c}\text { Tomato- } \\
\text { Loyals } \\
\end{array}$ & Sensorialists & $\begin{array}{c}\text { Health- } \\
\text { Conscious }\end{array}$ & \\
\hline Gender & $\begin{array}{l}\text { Male } \\
\text { Female }\end{array}$ & $\begin{array}{l}37.9 \% \\
62.1 \%\end{array}$ & $\begin{array}{l}42.5 \% \\
57.5 \%\end{array}$ & $\begin{array}{l}36.0 \% \\
64.0 \%\end{array}$ & $x^{2}(2)=1.084, p>0,05$ \\
\hline Age group & $\begin{array}{l}18-25 \\
26-35 \\
36-45 \\
46-55 \\
56-65 \\
66+\end{array}$ & $\begin{array}{r}28.8 \% \\
33.3 \% \\
12.1 \% \\
10.6 \% \\
13.6 \% \\
1.5 \% \\
\end{array}$ & $\begin{array}{r}19.8 \% \\
26.4 \% \\
17.0 \% \\
12.3 \% \\
17.9 \% \\
6.6 \%\end{array}$ & $\begin{array}{l}14.4 \% \\
21.6 \% \\
15.8 \% \\
25.9 \% \\
11.5 \% \\
10.8 \% \\
\end{array}$ & $\begin{array}{r}\text { Kruskal-Wallis Test: } \\
\mathrm{p}<0.05^{*} \\
\text { Post-hoc Mann-Whitney Test: } \\
\text { TL-S: } \mathrm{p}>0,0167 \\
\text { TL-HC: } \mathrm{p}<0,0167^{*} \\
\text { S-HC: } \mathrm{p}>0,0167\end{array}$ \\
\hline Marital Status & $\begin{array}{l}\text { Single } \\
\text { Married } \\
\text { Divorced } \\
\text { Widowed } \\
\end{array}$ & $\begin{array}{r}60.6 \% \\
30.3 \% \\
3.0 \% \\
6.1 \% \\
\end{array}$ & $\begin{array}{r}39.6 \% \\
57.5 \% \\
1.9 \% \\
0.9 \% \\
\end{array}$ & $\begin{array}{r}33.8 \% \\
57.6 \% \\
3.6 \% \\
5.0 \% \\
\end{array}$ & $\mathrm{x}^{2}(6)=19.612, \mathrm{p}<0,05^{*}$ \\
\hline Education & $\begin{array}{l}\text { Primary Education } \\
\text { Secondary Education } \\
\text { Higher Education }\end{array}$ & $\begin{array}{l}13.6 \% \\
28.8 \% \\
57.6 \% \\
\end{array}$ & $\begin{array}{l}10.4 \% \\
31.1 \% \\
58.5 \% \\
\end{array}$ & $\begin{array}{r}6.5 \% \\
34.5 \% \\
59.0 \% \\
\end{array}$ & $\begin{array}{r}\text { Kruskal-Wallis Test: } \\
\mathrm{p}>0.05\end{array}$ \\
\hline $\begin{array}{l}\text { Household } \\
\text { Income } \\
\text { per month } \\
\text { before tax }\end{array}$ & $\begin{array}{l}\text { Up to } 750 \text { Euros } \\
751-1000 \text { Euros } \\
\text { 1001-1500 Euros } \\
\text { 1501-1750 Euros } \\
\text { 1751-2000 Euros } \\
\text { 2001-2500 Euros } \\
\text { 2501-3000 Euros } \\
\text { More than 3001 Euros }\end{array}$ & $\begin{array}{r}16.7 \% \\
10.6 \% \\
21.2 \% \\
16.7 \% \\
12.1 \% \\
9.1 \% \\
6.1 \% \\
7.6 \%\end{array}$ & $\begin{array}{r}10.4 \% \\
6.6 \% \\
29.2 \% \\
17.0 \% \\
16.0 \% \\
7.5 \% \\
7.5 \% \\
5.7 \%\end{array}$ & $\begin{array}{r}4.3 \% \\
8.6 \% \\
17.3 \% \\
14.4 \% \\
19.4 \% \\
10.8 \% \\
14.4 \% \\
10.8 \%\end{array}$ & $\begin{array}{r}\text { Kruskal-Wallis Test: } \\
\mathrm{p}<0.05^{*} \\
\text { Post-hoc Mann-Whitney Test: } \\
\text { TL-S: } p>0,0167 \\
\text { TL-HC: }<<0,0167^{*} \\
\text { S-HC: } \mathrm{p}<0,0167^{*}\end{array}$ \\
\hline $\begin{array}{l}\text { Working mother } \\
\text { in the household }\end{array}$ & $\begin{array}{l}\text { Yes } \\
\text { No }\end{array}$ & $\begin{array}{l}39.4 \% \\
60.6 \%\end{array}$ & $\begin{array}{l}30.2 \% \\
69.8 \%\end{array}$ & $\begin{array}{l}54.0 \% \\
46.0 \%\end{array}$ & $\mathrm{x}^{2}(2)=14.269, \mathrm{p}<0,05^{*}$ \\
\hline $\begin{array}{l}\text { Underage } \\
\text { member in the } \\
\text { household }\end{array}$ & $\begin{array}{l}\text { Yes } \\
\text { No }\end{array}$ & $\begin{array}{l}18.2 \% \\
81.8 \%\end{array}$ & $\begin{array}{l}21.7 \% \\
78.3 \%\end{array}$ & $\begin{array}{l}21.6 \% \\
78.4 \%\end{array}$ & $\mathrm{x}^{2}(2)=0.375, \mathrm{p}>0,05$ \\
\hline
\end{tabular}

* Statistically significant difference 


\section{Purchasing behaviour of tomato consumers}

"Tomato-Loyals" select fresh tomatoes based on the following order of importance: price, tomatoes being in season or not, and country of origin. "Sensorialists" select fresh tomatoes based on another order though: country of origin, price and whether tomatoes are in season or not. The three most important purchasing criteria for "Health Conscious" are: country of origin, buying tomatoes in season, and the region of origin (within Greece). Statistically significant differences were found between "Tomato-Loyals" and "Sensorialists" in relation to the importance of buying tomatoes in season (or not), with "Sensorialists" displaying a higher degree of interest towards this criterion. "Tomato-Loyals" and "Health-Conscious" differ significantly regarding the criteria of purchasing tomatoes in season (or not), country of origin, the region of origin of tomatoes produced in Greece, and whether they are organic or not, whilst "Health-Conscious" displayed higher means for all criteria.

"Tomato-Loyals" and "Sensorialists" prefer to purchase tomatoes mainly from open markets. In contrast, "Health-Conscious" prefer to purchase tomatoes mainly from grocery shops. In terms of consumption frequency and consumed quantity in and off season, significant differences were found between "Sensorialists" and "HealthConscious". Moreover, the mean of the variable "Consumed Quantity in season" was found significantly different between "Tomato-Loyals" and "Health-Conscious", with "Health-Conscious" displaying the highest mean (Table IV). Finally, no significant differences were found between segments regarding the form in which they purchase tomatoes as most participants buy only loose tomatoes.

When participants purchase fresh tomatoes they look for information in relation to production method, quality class, date of harvest, date of last spraying, quality certification by the EU or the Greek Ministry of Rural Development, expiring date and information about the producer. Significant differences were found between "Tomato-Loyals" and "Health-Conscious" with "Health-Conscious" displaying the highest means. "Tomato-Loyals" and "Sensorialists" also differ significantly for information regarding the date of last spraying, quality certification and the producer with "Sensorialists" displaying the highest means (Table IV).

In relation to the consumption of organic tomatoes, 107 participants (34\%) stated that they eat organic tomatoes; therefore, the analysis of participants' attitudes and behaviour is based on these answers. Significant differences were found between the segments for organic tomato consumption $\left(\chi^{2}(2)=8.590, p<0.05\right)$. In particular, $41.7 \%$ 
of "Health-Conscious" eat organic tomatoes, while the percentage for "TomatoLoyals" and "Sensorialists" was 21.2\% and 33\% respectively. Significant differences were found between "Sensorialists" and "Health-Conscious" with respect to purchasing outlets for organic tomatoes (Table IV).

Table IV: Segments' purchasing behaviour for fresh tomatoes

\begin{tabular}{|c|c|c|c|c|c|}
\hline Variables & $\begin{array}{l}\text { Tomato- } \\
\text { Loyals } \\
\text { Mean }\end{array}$ & $\begin{array}{c}\text { Sensorialists } \\
\text { Mean }\end{array}$ & $\begin{array}{c}\text { Health- } \\
\text { Conscious } \\
\text { Mean }\end{array}$ & $\begin{array}{c}\text { Importance of } \\
\text { Differences between } \\
\text { Segments } \\
\text { Kruskal-Wallis } \\
\text { Test } \\
\end{array}$ & $\begin{array}{c}\text { Post-hoc Tests } \\
\text { between Segments } \\
\text { Mann-Whitney Test }\end{array}$ \\
\hline \multicolumn{6}{|c|}{ Purchasing Criteria for Fresh Tomatoes } \\
\hline Price & 3.20 & 3.26 & 3.12 & $\mathrm{p}>0.05$ & - \\
\hline If In Season & 3.11 & 3.22 & 3.36 & $\mathrm{p}<0.05^{*}$ & TL-HC: $\mathrm{p}<0.0167^{*}$ \\
\hline $\begin{array}{l}\text { Country of Origin (If } \\
\text { imported) }\end{array}$ & 3.00 & 3.38 & 3.40 & $\mathrm{p}<0.05^{*}$ & $\begin{array}{r}\text { TL-S: } \mathrm{p}<0.0167^{*} \\
\text { TL-HC: } \mathrm{p}<0.0167^{*}\end{array}$ \\
\hline Region of Origin (in Greece) & 2.89 & 3.00 & 3.22 & $\mathrm{p}<0.05^{*}$ & TL-HC: $\mathrm{p}<0.0167^{*}$ \\
\hline If Organic & 2.23 & 2.48 & 2.65 & $\mathrm{p}<0.05^{*}$ & TL-HC: $\mathrm{p}<0.0167^{*}$ \\
\hline Tomato Variety & 1.89 & 1.90 & 2.22 & $\mathrm{p}<0.05^{*}$ & S-HC: $\mathrm{p}<0.0167^{*}$ \\
\hline \multicolumn{6}{|l|}{ Outlets } \\
\hline Grocery Shop & 2.67 & 2.70 & 2.95 & $\mathrm{p}<0.05^{*}$ & S-HC: $p<0.0167^{*}$ \\
\hline $\mathrm{S} / \mathrm{M}$ in neighbourhood & 2.33 & 2.16 & 2.35 & $\mathrm{p}>0.05$ & \\
\hline $\mathrm{S} / \mathrm{M}$ out of the city & 1.86 & 1.49 & 1.76 & $\mathrm{p}<0.05^{*}$ & $\begin{array}{l}\text { TL-S: } \mathrm{p}<0.0167^{*} \\
\text { S-HC: } \mathrm{p}<0.0167^{*}\end{array}$ \\
\hline Open Market & 2.92 & 2.99 & 2.86 & $\mathrm{p}>0.05$ & - \\
\hline $\begin{array}{l}\text { Consumption Frequency } \\
\text { In Season }\end{array}$ & 2.28 & 2.39 & 2.17 & $\mathrm{p}>0.05$ & \\
\hline $\begin{array}{l}\text { Consumption Frequency } \\
\text { Off Season }\end{array}$ & 3.53 & 3.85 & 3.52 & $\mathrm{p}<0.05^{*}$ & S-HC: $\mathrm{p}<0.0167^{*}$ \\
\hline $\begin{array}{l}\text { Consumed Quantity In } \\
\text { Season }\end{array}$ & 4.12 & 4.37 & 4.69 & $\mathrm{p}<0.05^{*}$ & TL-HC: $\mathrm{p}<0.0167^{*}$ \\
\hline $\begin{array}{l}\text { Consumed Quantity Off } \\
\text { Season }\end{array}$ & 2.36 & 2.37 & 2.80 & $\mathrm{p}<0.05^{*}$ & S-HC: $\mathrm{p}<0.0167^{*}$ \\
\hline \multicolumn{6}{|l|}{ Information on the Label } \\
\hline Origin & 3.55 & 3.67 & 3.72 & $\mathrm{p}>0.05$ & - \\
\hline Price & 3.70 & 3.74 & 3.55 & $\mathrm{p}>0.05$ & - \\
\hline Production Method & 2.88 & 3.29 & 3.43 & $\mathrm{p}<0.05^{*}$ & TL-HC: $\mathrm{p}<0.0167^{*}$ \\
\hline Class & 2.94 & 3.14 & 3.34 & $\mathrm{p}<0.05^{*}$ & TL-HC: $\mathrm{p}<0.0167^{*}$ \\
\hline Date of harvest & 2.80 & 3.15 & 3.31 & $\mathrm{p}<0.05^{*}$ & TL-HC: $\mathrm{p}<0.0167^{*}$ \\
\hline Date of last spraying & 2.59 & 2.97 & 3.15 & $\mathrm{p}<0.05^{*}$ & $\begin{array}{r}\text { TL-S: } \mathrm{p}<0.0167^{*} \\
\text { TL-HC: } \mathrm{p}<0.0167^{*}\end{array}$ \\
\hline Quality Certification & 2.92 & 3.44 & 3.37 & $\mathrm{p}<0.05^{*}$ & $\begin{array}{r}\text { TL-S: } \mathrm{p}<0.0167^{*} \\
\text { TL-HC: } \mathrm{p}<0.0167^{*}\end{array}$ \\
\hline Expiring Date & 3.12 & 3.53 & 3.75 & $\mathrm{p}<0.05^{*}$ & TL-HC: $\mathrm{p}<0.0167^{*}$ \\
\hline Producer & 2.88 & 3.71 & 3.45 & $\mathrm{p}<0.05^{*}$ & TL-S: $\mathrm{p}<0.0167^{*}$ \\
\hline \multicolumn{6}{|c|}{ Outlets for Organic Tomatoes** } \\
\hline Organic Specialist Shop & 2.00 & 2.09 & 2.67 & $\mathrm{p}<0.05^{*}$ & S-HC: $\mathrm{p}<0.0167^{*}$ \\
\hline Grocery Shop & 2.14 & 2.06 & 2.67 & $\mathrm{p}<0.05^{*}$ & S-HC: $\mathrm{p}<0.0167^{*}$ \\
\hline $\mathrm{S} / \mathrm{M}$ in neighbourhood & 1.93 & 1.80 & 1.93 & $\mathrm{p}>0.05$ & - \\
\hline S/M out of the city & 2.14 & 1.76 & 2.03 & $\mathrm{p}>0.05$ & - \\
\hline Open market & 2.00 & 2.42 & 1.86 & $\mathrm{p}>0.05$ & \\
\hline
\end{tabular}

* Statistically significant difference

** Based on the replies of 107 consumers of the sample who eat organic tomatoes 
In addition, significant differences were found between "Tomato-Loyals" and "Health-Conscious" for the following statements: "Organic tomatoes are healthier than conventional" and "I decide in the outlet if I will buy organic or conventional tomatoes". "Health-Conscious" displayed the highest means (Table V).

Statistically significant differences were found between "Health-Conscious" and the other segments for their objective knowledge of the nutritional value of tomato as "Health-Conscious" have the highest level of agreement for the statements "Tomato contains vitamin $\mathrm{C}$ and amino acids", and "Tomato contains antioxidants" (Table V).

Table V: Participants' attitudes towards fresh tomatoes

\begin{tabular}{|c|c|c|c|c|c|}
\hline Variables & $\begin{array}{c}\text { Tomato- } \\
\text { Loyals } \\
\text { Mean }\end{array}$ & Mean & $\begin{array}{c}\text { Health- } \\
\text { Conscious } \\
\text { Mean }\end{array}$ & $\begin{array}{c}\text { Importance of } \\
\text { Differences between } \\
\text { Segments } \\
\text { Kruskal-Wallis Test }\end{array}$ & $\begin{array}{c}\text { Post-hoc Tests } \\
\text { between Segments } \\
\text { Mann-Whitney Test }\end{array}$ \\
\hline \multicolumn{6}{|c|}{ Statements for Organic Tomatoes** } \\
\hline $\begin{array}{l}\text { Organic tomatoes are } \\
\text { healthier than conventional. }\end{array}$ & 3.73 & 4.31 & 4.57 & $\mathrm{p}<0.05^{*}$ & TL-HC: $\mathrm{p}<0.0167^{*}$ \\
\hline $\begin{array}{l}\text { I decide in the outlet if I will } \\
\text { buy organic or conventional } \\
\text { tomatoes }\end{array}$ & 3.13 & 3.66 & 3.81 & $\mathrm{p}<0.05^{*}$ & TL-HC: $\mathrm{p}<0.0167^{*}$ \\
\hline $\begin{array}{l}\text { I trust the organic products } \\
\text { certification system }\end{array}$ & 3.47 & 3.51 & 3.48 & $\mathrm{p}>0.05$ & - \\
\hline \multicolumn{6}{|c|}{ Consumers' objective knowledge about the nutritional value of tomato and vegetables } \\
\hline $\begin{array}{l}\text { Tomato contains vitamin } \mathrm{C} \\
\text { and amino acids. }\end{array}$ & 3.52 & 3.23 & 3.89 & $\mathrm{p}<0.05^{*}$ & $\begin{array}{r}\text { TL-S: } p>0.0167 \\
\text { TL-HC: } \mathrm{p}<0.0167^{*} \\
\text { S-HC: } \mathrm{p}<0.0167^{*}\end{array}$ \\
\hline $\begin{array}{l}\text { Tomato contains } \\
\text { antioxidants }\end{array}$ & 3.86 & 3.74 & 4.35 & $\mathrm{p}<0.05^{*}$ & $\begin{array}{r}\text { TL-S: } p>0.0167 \\
\text { TL-HC: } p<0.0167^{*} \\
\text { S-HC: } p<0.0167^{*}\end{array}$ \\
\hline
\end{tabular}

\section{Discussion}

Many interesting differences were found between consumer segments. "HealthConscious" tend to eat tomatoes because they consider them as nutritional food. This preference is reflected on their consumption frequency. Specifically, they tend to eat more frequently larger quantities of tomatoes off season compared to "Sensorialists". In addition, "Health-Conscious" tend to prefer more expensive outlets compared to "Sensorialists", mainly due to their high income as well as because they may believe that they can find higher quality tomatoes. "Health-Conscious" tend to eat organic tomatoes more frequently compared to "Tomato-Loyals" and "Sensorialists", and displayed the highest degree of agreement with the statement "Organic tomatoes are healthier than conventional". This is in line with the findings of Pieniak et al. (2010b) 
who suggest that subjective knowledge is an important factor in organic vegetables consumption, as when people believe that they are knowledgeable about a food product, they might increase its consumption.

Our findings also concur with the findings of Pieniak et al. (2010a) as no statistically significant differences were found between segments regarding gender. The study of Pieniak et al. (2010a) focuses on fish consumption; however, both tomato and fish consumption are parts of a healthy food related lifestyle, and parts of the grocery shopping which tends to be carried out by the same member of a household. These non-statistically significant differences in relation to gender can be explained by the requirement for participants to be responsible for food purchases in their households. Women tend to be overrepresented in the study, as they are responsible for food purchases of most households in Greece (as well as in Thessaloniki) and around the world (Botonaki and Mattas, 2010).

"Health-Conscious" tend to purchase organic tomatoes mainly from speciality shops, which contrasts the findings of Perez-Cueto et al. (2010) who argue that Greek consumers do not prefer speciality shops for their food purchases. In addition, the percentage of "Tomato-Loyals" who eat organic tomatoes $(21.2 \%)$ was significantly lower than the percentage of regular organic food consumers in Greece (36\%) found by Ness et al. (2010). This once again supports our argument that segmentation can lead to more efficient social marketing and policy campaigns.

In relation to seasonal consumption of tomatoes, statistically significant differences were found between "Sensorialists" and "Health Conscious". This is in agreement with the findings of Locke et al. (2009) who suggest that seasonal consumption is an important factor when examining the consumption of particular types of vegetables. In our study, this reflects the preference of participants for tomatoes produced in Greece, and explains the seasonal consumption of tomatoes, as most tomatoes which are available in the market off season are imported.

Quality certification was also found as an important quality cue for "Sensorialists" and "Health Conscious". This contrasts the findings of Botonaki et al. (2006), who found that Greek consumers have a low degree of awareness about quality certifications on vegetables, tomatoes included, especially for vegetables produced based on low input of pesticides and fertilizers. This indicates that consumers' attitudes towards food safety have changed over the past few years, following several food scare incidents, and therefore consumers tend to seek quality certifications even 
for foods which were not highly related to food scares in the past, such as tomatoes and other vegetables.

The differences between "Tomato-Loyals" and the other segments in relation to the information that they would like to have available when they buy tomatoes can be mainly explained by the difference in age. "Tomato-Loyals" is the youngest segment and they tend to be less worried about their health compared to older consumers (Berning et al., 2010). These differences also illustrate that although tomatoes are a low involvement food product (Gething et al., 2011), "Health-Conscious" consumers display a higher purchase involvement compared to "Tomato-Loyals" as they tend to consider that the more information the better when they buy tomatoes.

The identification of three tomato consumer segments in this study is in agreement with the number of tomato consumer segments identified by Le and Ledauphin (2006) in France; however, there are differences regarding their characteristics. "TomatoLoyals", identified in this study as the youngest consumer segment, represent $21.2 \%$ of our sample whereas the youngest segment identified by Le and Ledauphin (2006) represents $39.6 \%$ of their sample. In addition, all segments identified in our study are price-conscious, however, only the oldest segment identified by Le and Ledauphin (2006) displays similar behaviour. This can be explained by the lower disposable income of Greek households compared to their French counterparts (Euromonitor International, 2011).

Furthermore, "Tomato-Loyals" tend to purchase only loose tomatoes, whereas members of the youngest segment identified by Bertail and Caillavet (2008) in examining vegetable consumption, tomatoes included, tend to prefer buying other frozen vegetables and convenience foods and this is mainly due to the lack of free time. Despite this lack of free time which all consumers experience nowadays, the preference of "Tomato-Loyals" to buy only fresh tomatoes illustrates an underlying willingness to adopt a healthier diet, which can be achieved if they are targeted with appropriate social marketing and policy campaigns. The reason to compare these segments in this study with vegetable consumer segments identified in France is that France is ranked third in terms of obesity among the Mediterranean countries following Greece and Malta. Therefore, given that limited information is available about vegetable consumer segments in Malta, examining the differences between Greek and French consumer segments can provide marketing and policy insights towards the adoption of healthy diets in Mediterranean countries. 


\section{Conclusions}

The study contributes to the consumer segmentation literature as it has revealed the basic characteristics of tomato consumer segments. The findings can be employed both by food policy makers in designing interventions in food consumption to tackle obesity, and by food marketers in targeting the appropriate consumer segments when marketing tomato products in Greece and throughout Europe. The findings indicate that "Tomato-Loyals" display the lowest consumption, the lowest degree of objective knowledge about the nutritional value of tomatoes, and a low level of purchase involvement. Therefore, health marketing and policy campaigns targeting consumers of this segment should aim to increase awareness of these consumers in relation to the nutritional value of tomatoes and ,their relatively low price. The latter is very important considering the high price sensitivity of this segment. Marketing and policy campaigns should also promote consumption of other vegetables, as when tomato is off season this segment reduces substantially the overall vegetable consumption (determined mainly from tomato intake). Subsequently, further actions should be taken to ensure the supply of tomatoes off season as this is important for "TomatoLoyals" who do not eat other vegetables. Health marketing and policy campaigns targeting "Tomato-Loyals" should also aim to increase the level of organic tomato consumption of this segment, as "Tomato-Loyals" display a low consumption of organic tomatoes despite their belief that organic tomatoes are healthier than conventional. Marketing and policy campaigns should therefore stress the nutritional and the environmental benefits from the consumption of organic products . It is worth stressing that "Tomato-Loyals" is the youngest segment and younger consumers tend to be more sensitive towards environmental issues. We believe that an increase in organic tomato consumption may also lead to an increase in vegetable consumption in general. Health marketing and policy campaigns targeting "Sensorialists" and "Health-Conscious" should focus on the quality characteristics and the nutritional value of tomatoes respectively. Therefore, these campaigns should promote the use of nutritional labels, which will provide the information that consumers sought. The display of nutrition labels providing that information, should be compulsory for food companies, even for producers of loose tomatoes. This intervention might increase the consumption of tomatoes in Greece and throughout Europe as the campaigns will focus on the importance of this information in relation to citizen's health. This could contribute to the improvement of dietary habits and behaviour of Greek, or even 
European, consumers too. The intervention can be expanded by introducing compulsory shelf labels in food stores and in open markets which could contribute to a significant increase in tomato consumption. The recommended health marketing and policy campaigns should target female consumers who are mainly responsible for the grocery shopping and influence consumption behaviour of all household members. Similar social marketing and policy campaigns can be applied to other European countries in general, and to other Mediterranean countries in particular, such as France and Spain in order to address obesity problems and to reduce public health expenses. This is very important for many Mediterranean countries (e.g. Greece, Spain, Portugal) which are currently facing major financial problems.

The study has a few limitations. It is based on self-reported behaviour where participants may over-report their replies to display a socially desirable behaviour (Geeroms et al., 2008). The cross-sectional design of the study may also prevent the generalisation of the findings. However, these limitations apply to most consumer behaviour studies and future research can duplicate this study to examine the stability of the segments and to assess the validity of the scales. Given the current uncertain financial climate in Europe, and the importance of tackling obesity in reducing the health care expenses in most European countries, future research can examine tomato consumption on pan-European level, focusing on how consumers use the tomatoes they purchase. Future studies can also examine the consumption of processed tomato products which can also contribute to achieving the recommended five servings of vegetables per day.

\section{References}

Barreiro-Hurle, J., Gracia, A. and De-Magistris, T. (2010), "Does nutrition information on food products lead to healthier food choices?", Food Policy, Vol. 35, pp. 221-229.

Berning, J. P., Chouinard, H. H., Manning, K. C., Mccluskey, J. J. and Sprott, D. E. (2010), "Identifying consumer preferences for nutrition information on grocery store shelf labels", Food Policy, Vol. 35, No. 5, pp. 429-436.

Bertail, P. and Caillavet, F. (2008), "Fruit and vegetable consumption patterns: A segmentation approach", American Journal of Agricultural Economics, Vol. 90, No. 3, pp. 827-842.

Binnekamp, M. and Ingenbleek, P. (2008), "Do "good" food products make others look "bad"? Spin-off effects of labels for sustainable food production in the consumer perception", British Food Journal, Vol. 110, No. 9, pp. 843-864. 
Boccaletti, S. and Nadella, M. (2000), "Consumer willingness to pay for pesticidefree fresh fruit and vegetables in Italy", International Food and Agribusiness Management Review, Vol. 3, pp. 297-310.

Botonaki, A. and Mattas, K. (2010), "Revealing the values behind convenience food consumption", Appetite, Vol. 55, pp. 629-638.

Botonaki, A., Polymeros, K., Tsakiridou, E. and Mattas, K. (2006), "The role of food quality certification on consumers' food choices", British Food Journal, Vol. 108, No. 2, pp. 77-90.

Browyer, S., Caraher, M., Eilbert, K. and Carr-Hill, R. (2009), "Shopping for food: lessons from a London borough", British Food Journal, Vol. 111, No. 5, pp. 452-474.

Brueckner, B., Schonhof, I., Schroedter, R. and Kornelson, C. (2007), "Improved flavour acceptability of cherry tomatoes. Target group: Children", Food Quality and Preference, Vol. 18, pp. 152-160.

Causse, M., Friquet, C., Coiret, C., Lepicier, M., Navez, B., Lee, M., Holthuysen, N., Sinesio, F., Moneta, E. and Grandillo, S. (2010), "Consumer preferences for fresh tomato at the European scale: A common segmentation on taste and firmness", Journal of Food Science, Vol. 75, No. 9, pp. S531-S541.

Chang, C. H., Lin, H. Y., Chang, C. Y. and Liu, Y. C. (2006), "Comparisons on the antioxidant properties of fresh, freeze-dried and hot-air-dried tomatoes", Journal of Food Engineering, Vol. 77, No. 3, pp. 478-485.

Chrysochou, P., Askegaard, S., Grunert, K. G. and Kristensen, D. B. (2010), "Social discourses of healthy eating. A market segmentation approach", Appetite, Vol. 55, pp. 288-297.

Espejel, J., Fandos, C. and Flavian, C. (2008), "Consumer satisfaction a key factor of consumer loyalty and buying intention of a PDO food product" British Food Journal, Vol. 110, No. 9, pp. 865-881.

Euromonitor International (2011), "Annual disposable income in Europe", available at: http://www.portal.euromonitor.com/Portal/Pages/Statistics/Statistics.aspx (accessed 20 April 2011).

European Commission (2009), "European nutrition and health report 2009", available at: http://www.univie.ac.at/enhr/ (accessed 10 November 2010).

Field, A. (2005), Discovering Statistics Using SPSS, 2nd Edition, Sage Publications, London.

Fotopoulos, C. and Krystallis, A. (2003), "Quality labels as a marketing advantage. The case of the "PDO Zagora" apples in the Greek market", European Journal of Marketing, Vol. 37, No. 10, pp. 1350-1374.

Frusciante, L., Carli, P., Ercolano, M. R., Pernice, R., Matteo, A. D., Fogliano, V. and Pellegrini, N. (2007), "Antioxidant nutritional quality of tomato", Molecular Nutrition and Food Research, Vol. 51, No. 5, pp. 609-617.

Geeroms, N., Verbeke, W. and Kenhove, P. V. (2008), "Health advertising to promote fruit and vegetable intake: Application of health-related motive segmentation", Food Quality and Preferences, Vol. 19, pp. 481-497. 
Gething, K., Smyth, H., Kirchhoff, S., Sanderson, J. and Sultanbawa, Y. (2011), "Increasing vegetable consumption: a means-end chain approach", British Food Journal, Vol. 13, No. 8, early citation.

Grunert, K. G., Juhl, H. J., Esbjerg, L., Jensen, B. B., Bech-Larsen, T., Brunso, K. and Madsen, C. O. (2009), "Comparing methods for measuring consumer willingness to pay for a basic and an improved ready made soup product", Food Quality and Preference, Vol. 20, pp. 607-619.

Grunert, K. G., Perrea, T., Zhou, Y., Huang, G., Sorensen, B. T. and Krystallis, A. (2011), "Is food-related lifestyle (FRL) able to reveal food consumption patterns in non-Western cultural environments? Its adaptation and application in urban China", Appetite, Vol. 56, No. 2, pp. 357-367.

Guerrero, L., Guardia, M. D., Xicola, J., Verbeke, W., Vanhonacker, F., ZakowskaBiemans, S., Sajdakowska, M., Sulmont-Rosse, C., Issanchou, S., Contel, M., Scalvedi, M. L., Granli, B. S. and Hersleth, M. (2009), "Consumer-driven definition of traditional food products and innovation in traditional foods. A qualitative cross-cultural study", Appetite, Vol. 52, pp. 345-354.

Hjelmar, U. (2011), "Consumers' purchase of organic food products. A matter of convenience and reflexive practices", Appetite, Vol. 56, pp. 336-344.

Hoefkens, C., Verbeke, W. and Camp, J. V. (2011), "European consumers' perceived importance of qualifying and disqualifying nutrients in food choices", Food Quality and Preference, Vol. 22, pp. 550-558.

Honkanen, P. (2010), "Food preference based segments in Russia", Food Quality and Preference, Vol. 21, pp. 65-74.

Jahns, G., Nielsen, H. M. and Paul, W. (2001), "Measuring image analysis attributes and modelling fuzzy consumer aspects for tomato quality grading", Computers and Electronics in Agriculture, Vol. 31, pp. 17-29.

Kemp, K., Insch, A., Holdsworth, D. K. and Knight, J. G. (2010), "Food miles: Do UK consumers actually care?", Food Policy, Vol. 35, pp. 504-513.

Korzen, S., Sandoe, P. and Lassen, J. (2011), "Don't wash my meat: public perceptions of decontamination in meat production", British Food Journal, Vol. 113, No. 5, pp. 598-612.

Le, S. and Ledauphin, S. (2006), "You like tomato, I like tomato: Segmentation of consumers with missing values", Food Quality and Preference, Vol. 17, pp. 228-233.

Leather, S. (1995), "Fruit and vegetables: consumption patterns and health consequences", British Food Journal, Vol. 97, No. 7, pp. 10-17.

Locke, E., Coronado, G. D., Thompson, B. and Kuniyuki, A. (2009), "Seasonal variation in fruit and vegetable consumption in a rural agricultural community", Journal of the American Dietetic Association, Vol. 109, No. 1, pp. 45-51.

Malhotra, N. K. and Birks, D. F. (2007), Marketing Research An Applied Approach, 3rd European Edition, Pearson Education Limited, Essex. 
Meneely, L., Strugnell, C. and Burns, A. (2009), "Elderly consumers and their food store experiences", Journal of Retailing and Consumer Services, Vol. 16, pp. 458-465.

Michaelidou, N. and Hassan, L. M. (2010), "Modeling the factors affecting rural consumers' purchase of organic and free-range produce: A case study of consumers' from the Island of Arran in Scotland, UK", Food Policy, Vol. 35, pp. 130-139.

Michon, C., O'Sullivan, M. G., Sheehan, E., Delahunty, C. M. and Kerry, J. P. (2010), "Study on the influence of age, gender and familiarity with the product on the acceptance of vegetable soups", Food Quality and Preference, Vol. 21, pp. 478-488.

Miljkovic, D. and Effertz, C. (2010), "Consumer behavior in food consumption: reference price approach", British Food Journal, Vol. 112, No. 1, pp. 32-43.

Nayga, R. (2008), "Nutrition, obesity and health: policies and economic research challenges", European Review of Agricultural Economics, Vol. 35. No. 3, pp. 281-302.

Ness, M., Brennan, M., Oughton, E., Ritson, C. and Ruto, E. (2010), “Modelling consumer behavioural intentions towards food with implications for marketing quality low-input and organic food", Food Quality and Preference, Vol. 21, pp. 100-111.

Norusis, M. J. (2007), SPSS 15.0 Guide to Data Analysis, Prentice Hall, New Jersey.

Pagliarini, E., Monteleone, E. and Ratti, S. (2001), "Sensory profile of eight tomato cultivars (Lycopersicon esculentum) and its relationship to consumer preference", Italian Journal of Food Science, Vol. 13, No. 3, pp. 285-296.

Perez-Cueto, F. J. A., Verbeke, W., Barcellos, M. D. D., Kehagia, O., Chryssochoidis, G., Scholderer, J. and Grunert, K. G. (2010), "Food-related lifestyles and their association to obesity in five European countries", Appetite, Vol. 54, pp. 156162.

Peterson, R. A. (1994), “A Meta-Analysis of Cronbach's Coefficient alpha”, The Journal of Consumer Research, Vol. 21, No. 2, pp. 381-391.

Pieniak, Z., Verbeke, V., Olsen, S. O., Hansen, K. B. and Brunso, K. (2010a), "Health-related attitudes as a basis for segmenting European fish consumers", Food Policy, Vol. 35, pp. 448-455.

Pieniak, Z., Aertsens, J. and Verbeke, W. (2010b), "Subjective and objective knowledge as determinants of organic vegetables consumption", Food Quality and Preference, Vol. 21, pp. 581-588.

Preedy, V. R. and Watson, R. R. (2008), Lycopene: Nutritional, Medical and Therapeutic Properties, Science Publishers, Enfield, NH, USA.

Ragaert, P., Verbeke, W., Devlieghere, F. and Debevere, J. (2004), "Consumer perception and choice of minimally processed vegetables and packaged fruits", Food Quality and Preference, Vol. 15, (259-270).

Thogersen, J. (2009), "Consumer decision-making with regard to organic food products", in Vaz, T. D., Nijkamp, P. and Rastoin, J. L. (Eds.), Traditional 
food production and rural sustainable development: A European challenge, Ashgate Publishing Limited, Surrey, UK, pp. 173-194.

Thogersen, J., Haugaard, P. and Olesen, A. (2010), "Consumer responses to ecolabels”, European Journal of Marketing, Vol. 44, No. 11/12, pp. 17871810 .

Trogdon, J. G., Finkelstein, E. A., Hylands, T., Dellea, P. S., and Kamal-Bahl, S. J. (2008), "Indirect costs of obesity: a review of the current literature", Obesity Reviews, Vol. 9, pp. 489-500.

Tsakiridou, E., Boutsouki, C., Zotos, Y. and Mattas, K. (2008), “Attitudes and behaviour towards organic products: an exploratory study", International Journal of Retail \& Distribution Management, Vol. 36, No. 2, pp. 158-175.

Tzavaras, M., Tzimitra-Kalogianni, I. and Bourlakis, M. (2010), "Consumer behaviour in the Greek floral market. Comparative insights for the food industry", British Food Journal, Vol. 112, No. 4, pp. 403-415.

Tzimitra-Kalogianni, I., Papadaki-Klavdianou, A., Alexaki, A. and Tsakiridou, E. (1999), "Wine routes in Northern Greece: consumer perceptions", British Food Journal, Vol. 101, No. 11, pp. 884-892.

Verbeke, W., Frewer, L. J., Scholderer, J. and Brabander, H. F. D. (2007), "Why consumers behave as they do with respect to food safety and risk information", Analytica Chimica Acta, Vol. 586, pp. 2-7.

Verbeke, W. and Pieniak, Z. (2006), "Benefit beliefs, attitudes, and behaviour towards fresh vegetable consumption in Poland and Belgium", Acta Alimentaria, Vol. 35, No. 1, pp. 5-16.

World Health Organisation (2009), "General government expenditure on health as a percentage of total", available at: http://apps.who.int/ghodata/?vid=1901\# (accessed 5 May 2011).

World Health Organisation (2011), "Global Database on Body Mass Index", available at: http://apps.who.int/bmi/index.jsp (accessed 25 January 2011). 


\section{Appendix - Survey Questionnaire}

Q1. Do you eat tomatoes?

\begin{tabular}{|l|l|l|l|}
\hline Yes & & No & \\
\hline
\end{tabular}

Notice: If answered yes proceed to question $\underline{\mathrm{Q2}}$ If answered no proceed to question $\underline{\mathbf{Q 1 5}}$

Q2. Why do you eat tomatoes? Express the degree to which you agree with the following statements.

\begin{tabular}{|l|l|l|l|l|}
\hline \multicolumn{1}{|c|}{ Statements } & $\begin{array}{c}\text { Totally } \\
\text { Agree }\end{array}$ & Agree & $\begin{array}{c}\text { Neither Agree / Nor } \\
\text { Disagree }\end{array}$ & $\begin{array}{c}\text { Disagree } \\
\text { Disagree }\end{array}$ \\
\hline $\begin{array}{l}\text { I like the flavour. } \\
\text { They have nice aroma. }\end{array}$ & & & & \\
It is nutritious food. & & & \\
It is healthy food. & & & \\
It is light food. & & & \\
I do not eat other vegetables as salad. \\
$\begin{array}{l}\text { It is a refreshing salad over summer. } \\
\text { They are rich in vitamins, fibres and } \\
\text { antioxidants. }\end{array}$
\end{tabular}

Q3. Which of the following criteria do you consider as important when you purchase tomatoes.

\begin{tabular}{|l|l|l|l|l|}
\hline \multicolumn{1}{|c|}{ Criteria } & Always & Usually & Rarely & Never \\
\hline Price & & & & \\
If in season & & & & \\
Country of Origin (If imported) & & & & \\
Region of Origin (In Greece) & & & & \\
If Organic & & & & \\
Tomato Variety & & & & \\
\hline
\end{tabular}

Q4. Where do you purchase tomatoes?

\begin{tabular}{|l|l|l|l|l|}
\hline \multicolumn{1}{|c|}{ Outlets } & Always & Usually & Rarely & Never \\
\hline Grocery Shop & & & & \\
S/M in neighbourhood & & & & \\
S/M out of city & & & & \\
Open Market & & & & \\
\hline
\end{tabular}

Q5. How often do you eat tomatoes In Season?

\begin{tabular}{|c|}
\hline $\begin{array}{c}\text { Consumption Frequency } \\
\text { In Season }\end{array}$ \\
\hline $\begin{array}{l}\text { Everyday } \\
2 \text { - } 3 \text { times per week } \\
\text { Once per week } \\
\text { Less than once per week } \\
\text { Every fortnight }\end{array}$ \\
\hline
\end{tabular}

Q6. How often do you eat tomatoes Off Season?

\begin{tabular}{|l|l|}
\hline \multicolumn{1}{|c|}{$\begin{array}{c}\text { Consumption Frequency } \\
\text { Off Season }\end{array}$} & \\
\hline Everyday & \\
2 - 3 times per week & \\
Once per week & \\
Less than once per week & \\
Every fortnight & \\
\hline
\end{tabular}


Q7. What quantity of tomatoes do you eat per week In Season?

\begin{tabular}{|l|l|}
\hline Less than $1 \mathrm{Kg}$ & \\
$1-1,5 \mathrm{Kg}$ & \\
$1,5-2 \mathrm{Kg}$ & \\
$2-3 \quad \mathrm{Kg}$ & \\
$3-4 \quad \mathrm{Kg}$ & \\
$4-5 \quad \mathrm{Kg}$ & \\
More than $5 \mathrm{Kg}$ & \\
\hline
\end{tabular}

Q8. What quantity of tomatoes do you eat per week Off Season?

\begin{tabular}{|l|l|}
\hline Less than $1 \mathrm{Kg}$ & \\
$1-1,5 \mathrm{Kg}$ & \\
$1,5-2 \mathrm{Kg}$ & \\
$2-3 \quad \mathrm{Kg}$ & \\
$3-4 \quad \mathrm{Kg}$ & \\
$4-5 \quad \mathrm{Kg}$ & \\
More than $5 \mathrm{Kg}$ & \\
\hline
\end{tabular}

Q9. In which form do you purchase tomatoes?

Only loose
Only packed fresh tomatoes
Both loose and packed

Q10. Which information would you like to have available on labels when you purchase tomatoes?

\begin{tabular}{|l|l|l|l|l|}
\hline \multicolumn{1}{|c|}{ Information } & Always & Usually & Rarely & Never \\
\hline Origin & & & & \\
Price & & & & \\
Production Method & & & & \\
Class & & & & \\
Date of harvest & & & & \\
Date of last spraying & & & & \\
Quality certification & & & & \\
Expiring Date & & & & \\
Producer & & & & \\
\hline
\end{tabular}

Q11. Do you eat organic tomatoes?

\begin{tabular}{|l|l|l|l|}
\hline Yes & & No & \\
\hline
\end{tabular}

Notice: If answered no proceed to question Q14

Q12. Where do you purchase organic tomatoes?

\begin{tabular}{|l|l|l|l|l|}
\hline Outlet for Organic Tomatoes & Always & Usually & Rarely & Never \\
\hline Organic Specialist Shop & & & & \\
Grocery Shop & & & & \\
S/M in neighbourhood & & & & \\
S/M out of city & & & & \\
Open market & & & & \\
\hline
\end{tabular}

Q13. Express the degree to which you agree or disagree with the following statements in relation to consumption of organic tomatoes.

\begin{tabular}{|c|c|c|c|c|c|}
\hline Statements & $\begin{array}{c}\text { Totally } \\
\text { Agree }\end{array}$ & Agree & $\begin{array}{c}\text { Neither } \\
\text { Agree/ } \\
\text { Nor Disagree }\end{array}$ & Disagree & $\begin{array}{c}\text { Totally } \\
\text { Disagre } \\
\text { e }\end{array}$ \\
\hline $\begin{array}{l}\text { Organic tomatoes are healthier than conventional. } \\
\text { I decide in the outlet if I will purchase organic or conventional } \\
\text { tomatoes. } \\
\text { I trust the organic products certification system. }\end{array}$ & & & & & \\
\hline
\end{tabular}


Q14. Express the degree to which you agree or disagree with the following statements in relation to consumer objective knowledge about the nutritional value of tomato and vegetables.

\begin{tabular}{|l|c|c|c|c|c|}
\hline \multicolumn{1}{|c|}{ Statements } & $\begin{array}{c}\text { Totally } \\
\text { Agree }\end{array}$ & Agree & $\begin{array}{c}\text { Neither } \\
\text { Agree/ } \\
\text { Nor Disagree }\end{array}$ & Disagree & $\begin{array}{c}\text { Totally } \\
\text { Disagree }\end{array}$ \\
\hline $\begin{array}{l}\text { Tomato contains vitamin C and amino acids. } \\
\text { Tomato contains antioxidants }\end{array}$ & & & & & \\
\hline
\end{tabular}

\section{Socioeconomic and Demographic Characteristics}

Q15. Gender

\begin{tabular}{|l|l|l|l|} 
Male & Female & \\
\hline
\end{tabular}

Q16. Age Group

\begin{tabular}{|l|l|}
\hline $18-25$ & \\
$26-35$ & \\
$36-45$ & \\
$46-55$ & \\
$56-65$ & \\
66 or older & \\
\hline
\end{tabular}

Q17. Marital Status

\section{Single}

Maried

Divorced

Widowed

\section{Q18. Education}

\begin{tabular}{|l|l|}
\hline Primary Education & \\
Secondary Education & \\
Higher Education & \\
\hline
\end{tabular}

Q19. Working mother in the household

\begin{tabular}{|l|l|l|l|}
\hline Yes & & No & \\
\hline
\end{tabular}

Q20. Underage member in the household

\begin{tabular}{|l|l|l|l|}
\hline Yes & & No & \\
\hline
\end{tabular}

Q21. Household Income per month before tax

$$
\begin{aligned}
& \text { Up to } 750 € \\
& 751-1000 € \\
& 1001-1500 € \\
& 1501-1750 € \\
& 1751-2000 € \\
& 2001-2500 € \\
& 2501-3000 €
\end{aligned}
$$

More than $3001 €$ 